\title{
CONCEPÇÃO, MONTAGEM, E AVALIAÇÃO DA EXPOSIÇÃO TEMPORÁRIA "A VIDA EFÊMERA DOS OBJETOS: UM OLHAR PÓS- ENCHENTE" NO MUSEU GRUPPELLI, PELOTAS/RS
}

\author{
Maurício André Maschke Pinheiro \\ Aluno de Bacharelado em Museologia /UFPel \\ mauriciopinheiro685@gmail.com \\ José Paulo Siefert Brahm \\ Aluno do PPGMP da UFPel/Bolsista CAPES \\ josepbrahm@hotmail.com \\ Giovani Vahl Matthies \\ Aluno de Bacharelado em Museologia /UFPel \\ giovanimathies@gmail.com \\ Diego Lemos Ribeiro \\ Professor adjunto da UFPel \\ dlrmuseologo@yahoo.com
}

\section{RESUMO}

O texto que segue busca refletir sobre o processo expositivo concebido após evento traumático ocorrido no Museu Gruppelli. No dia 26 de março de 2016, a comunidade do Sétimo Distrito de Pelotas foi acometida por uma enchente de proporções inéditas. Casas e comércios da região sofreram enormes perdas. Com o Museu Gruppelli não foi diferente. Parte do acervo foi arrastado pela força da água, se perdeu, ou foi danificado, de forma irreversível. Entre as principais perdas do acervo está o tacho de cobre e a cadeira que ficava no cenário da barbearia. A partir desse acontecimento, elaboramos uma exposição temporária, intitulada "a vida efêmera dos objetos: um olhar pósenchente", que busca contar a história da tragédia ocorrida no Museu, através da visão dos objetos. Por esse contexto, o presente artigo tem por finalidade fazer um breve relato das etapas de concepção, montagem e avaliação da exposição temporária mencionada. Do mesmo modo, abre caminho para refletir sobre a musealização do ausente e do trato de acervos que passaram por eventos traumáticos.

Palavras- chave: Enchente; Musealização; Exposição; Museu Gruppelli. 


\section{INTRODUÇÃO}

O Museu Gruppelli fica localizado no $7^{\circ}$ distrito da cidade de Pelotas e foi inaugurado em outubro de 1998, por iniciativa da comunidade local. O acervo do Museu foi reunido através da coleta e de doações feitas por moradores da região, capitaneados pela família Gruppelli, cujo objetivo era reunir referências do patrimônio rural que fossem significativas para a população circunvizinha. $O$ contato com a comunidade local sempre foi mediado pela família, mas com uma visão comunitária aglutinadora.

Para Ricardo Gruppelli, a ideia da criação do Museu surgiu devido a muitas pessoas que vinham relembrar sua infância na colônia, como no caso de parentes, vizinhos e veranistas. A maioria dos objetos que faz parte do Museu já se encontrava no prédio em que ele se situa hoje. Com o decorrer do tempo, o número de objetos salvaguardados foi aumentando gradativamente, seja por doação da própria família Gruppelli, ou mesmo, por iniciativa de moradores locais que tiveram despertado o interesse em preservar as memórias do cotidiano dessa região.

Como a colônia é de uma fundação bem antiga, o pessoal despertou, valorizou. O pessoal olhava uma peça no Museu, uma enxada velha lá, sabe que eu tenho um enxadão lá que pode servir pro Museu. Então despertou esse resgate. Muita gente recolheu coisas que estavam atiradas no galpão, acondicionou melhor para preservar. Despertou a ideia de preservação (GRUPPELLI, 2016).

É importante mencionar que esses objetos, pelo menos do ponto de vista utilitário, hoje são pouco valorados por aqueles atores-sociais. Pelo olhar da materialidade e da funcionalidade, a maioria deixou de ser usado ao ser substituído por instrumentos e utensílios mais modernos. Do prisma patrimonial, leva-nos a crer que esses objetos, que chegaram ao fim de sua vida utilitária; eram como restos da vida social. Porém, o olhar lançado sobre os objetos, já enquadrados no conceito de acervo, extrapola, e muito, o valor meramente utilitário. A linha que separa descarte (lixo) da inserção no circuito patrimonial (acervo) muitas vezes é tênue. Houve, com essas 
coleções, a maioria formada por objetos obsoletos ${ }^{1}$, um processo de singularização ${ }^{2}$, com a intenção de preservá-los e difundi-los. Apesar de aparentemente banais, esses objetos foram selecionados por serem compreendidos como registros mnemônicos e identitários de suas histórias e da própria história da zona rural. Aos olhares de Candau (2014), como "extensões de memória."3 Nesse momento, muito desses objetos que se encontravam em final de existência, ganharam uma segunda chance, uma "segunda vida" (DEBARY, 2010). ${ }^{4}$ Ou seja, uma vida patrimonial.

Em 2008, no $10^{\circ}$ aniversário do Museu, a comunidade observou a necessidade de revitalizar o espaço museal. Percebeu-se que, se por um lado havia uma acentuada percepção do potencial patrimonial do espaço, por outro, o Museu padecia pela ausência de um olhar técnico-científico. Em outros termos, havia uma tácita percepção de que o Museu não havia amadurecido em termos de ações museológicas, apesar de sua significância para as memórias locais. A comunidade, então, solicitou apoio técnico à Universidade Federal de Pelotas (UFPel), por intermédio do Curso de Bacharelado em Museologia, objetivando uma melhor manutenção e gerenciamento das coleções. Foi nesse contexto, levando em consideração a importância patrimonial e turística do sítio, que surgiu o Projeto Revitalização do Museu Gruppelli.

O projeto nasce com o objetivo de aprimorar as condições ambientais da antiga adega onde se encontra o Museu. Reconfigurar a expografia e implantar um novo sistema de documentação. Quando a Universidade chegou ao Museu, encontrou um

${ }^{1} \mathrm{O}$ acervo do Museu é dividido em várias tipologias (esporte, doméstico, impressos, trabalho rural e trabalho especifico).

${ }^{2}$ A singularização é vista, aqui, como o oposto da comoditização. Nos circuitos patrimoniais, especialmente em museus, o movimento de singularização implica em transformar objetos/coisas, independentemente do sua expressão material ou imaterial, em algo único em seu significado. Por ser único e por ter valor atribuído, distingue-se das mercadorias, portanto não é vendável ou descartável.

3"Mesmo que as capacidades memoriais estritamente humanas sejam consideráveis, o homem quase nunca está satisfeito com seu cérebro como unidade única de estocagem de informações memorizadas e, desde muito cedo, recorre a extensões da memória" (CANDAU, 2014, p. 107).

${ }^{4}$ Para o autor, muitos objetos desde cobertores, armários ou mesmo cinzeiros, fuzis de caça, quadros, livros, quando chegam ao fim de sua vida utilitária, são geralmente descartados por seus usuários. Deixam de fazer parte da vida das pessoas ou grupo a qual fizeram parte. Não serão mais lembrados, e nem ajudarão a compor memórias e identidades. Porém, ao fim de sua vida, reivindicam um novo amanha, esperam por uma segunda chance, por um novo sopro, por um novo futuro. "Alguns serão escolhidos para serem reparados ou mesmo recuperados. Obterão a esperança de um novo futuro [...]" (DEBARY, 2010, p. 01). 
ambiente muito parecido com os "gabinetes de curiosidades", no qual havia um patente esvaziamento de significados dos objetos expostos. Vislumbrou-se, então, a necessidade de recuperar as memórias daquelas referências patrimoniais que estavam esmaecendo com o passar do tempo. O caminho seguido para evocar estas memórias foi a abertura ao diálogo com a comunidade local, o qual ocorreu em todos os momentos dessa intervenção museológica.

Diversas ações foram feitas desde 2008, até o momento, no Museu. Uma delas é a própria qualificação da exposição, que ampliou o potencial comunicativo, a exemplo da iluminação, do rearranjo dos objetos em nichos temáticos (trabalho rural, cozinha, esporte, vinho, etc.) e a própria coleta de depoimentos, que subsidia todas as etapas de revitalização. Os processos de comunicação ocupam lugar de destaque, atualmente, no Museu, plasmados em exposição de longa duração, exposições temporárias e no próprio diálogo travado com os moradores locais. A última exposição temporária foi uma homenagem aos noventa anos do Boa Esperança, time de futebol da colônia. Essas exposições temporárias temáticas são construídas com a participação de parcela da comunidade local, como no caso da exposição da costura ${ }^{5}$ e do futebol.

A equipe do Museu também vem desenvolvendo ações educativas, sobretudo com crianças. Essa ação teria partido de uma curiosidade, de uma dúvida, uma vez que parte considerável das crianças demonstra grande interesse pelo Museu e gosta de visitar e brincar no local. Surpreende-nos o fato de o Museu, considerado por muitos estático, concorrer com a paisagem e as possibilidades de entretenimento do lado de fora de suas paredes. A partir disso, vem sendo desenvolvida uma pesquisa dentro do Museu para entender o que chama a atenção dessas crianças nesse lugar.

Como processo metodológico, foi solicitado que as crianças desenhassem, de forma livre, o que elas mais gostaram em relação ao Museu. Muitas retrataram não somente o Museu, mas, a paisagem. Infere-se, assim, que o Museu não está isolado, mas que, na verdade, faz parte da paisagem. Em outros termos, a paisagem ajuda a compor seu discurso; mescla-se ao próprio Museu.

\footnotetext{
${ }^{5}$ A exposição da costura, intitulada "Costurando a Memória", realizada em 2012, teve como objetivo representar os modos de vida na zona rural por intermédio do ofício da costura, que vem se perdendo gradativamente. Para contextualizar o tema, coletamos depoimentos e vivências com antigas costureiras da região.
} 
O Museu ainda tem investido na questão da internet, ao criar um perfil no Facebook ${ }^{6}$ e no Instagram. As pessoas tiram fotos dentro do Museu, que são uma forma de compor a linguagem do mesmo; é realizada, ainda, uma série de atividades vinculadas a datas festivas, como dias das mães e dias das crianças, por exemplo.

Na véspera de Páscoa de 2016, a região do sétimo distrito de Pelotas foi atingida por uma enchente de proporções inéditas, que veio a trazer grandes prejuízos para a população local, com inúmeras perdas. No Museu Gruppelli não foi diferente, a água, que chegou perto de 1,20 metros de altura, inundou o espaço expositivo e a reserva técnica. Foram encontrados os objetos em meio à lama e água e, logo, foram notadas as ausências. Entre as principais perdas do acervo está o tacho de cobre e a cadeira que ficava no cenário da barbearia. (Figuras 1 e 2).

A partir desse acontecimento, de grande impacto simbólico e material, elaboramos uma exposição temporária, intitulada "a vida efêmera dos objetos: um olhar pós-enchente", com o objetivo de contar a história da tragédia ocorrida no Museu, através da visão dos objetos. Como argumento expositivo, partimos da ideia de que os objetos, assim como as pessoas, possuem vida efêmera, uma vez que nascem, vivem e morrem. Apresentamos os objetos em uma sequência que representa o ciclo de vida: aqueles que se foram, mas deixaram um legado; os que retornaram com cicatrizes e outros que estão recebendo uma nova chance de vida, por intermédio de um esforço cooperativo de diversas pessoas.

A partir desse contexto, o presente artigo tem por objetivo fazer um breve relato das etapas de concepção, montagem e avaliação da exposição temporária mencionada acima.

${ }^{6}$ Página disponível em: $\leq$ https://www.facebook.com/museugruppelli?fref=ts $>$. Acesso em: 03 jun. 2016. 


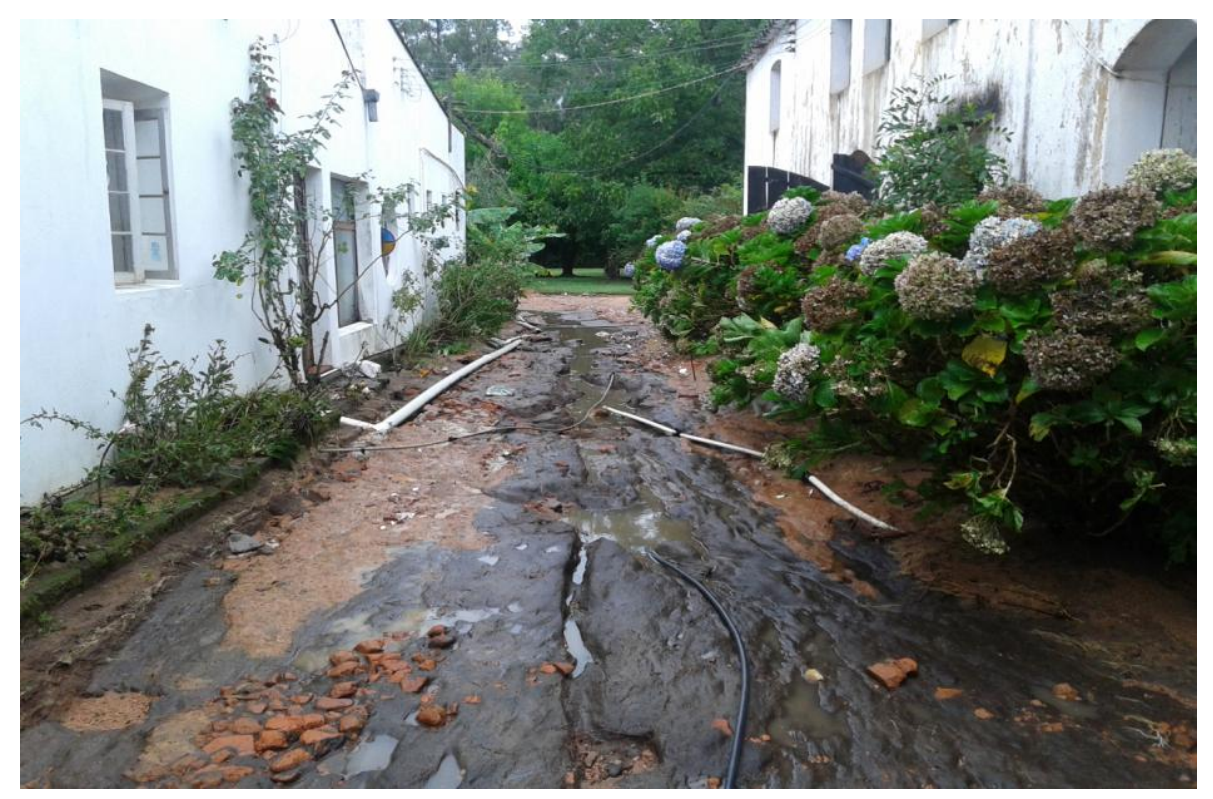

Figura 1: Pátio ao lado do Museu destruído

Fonte: Autores, 2016

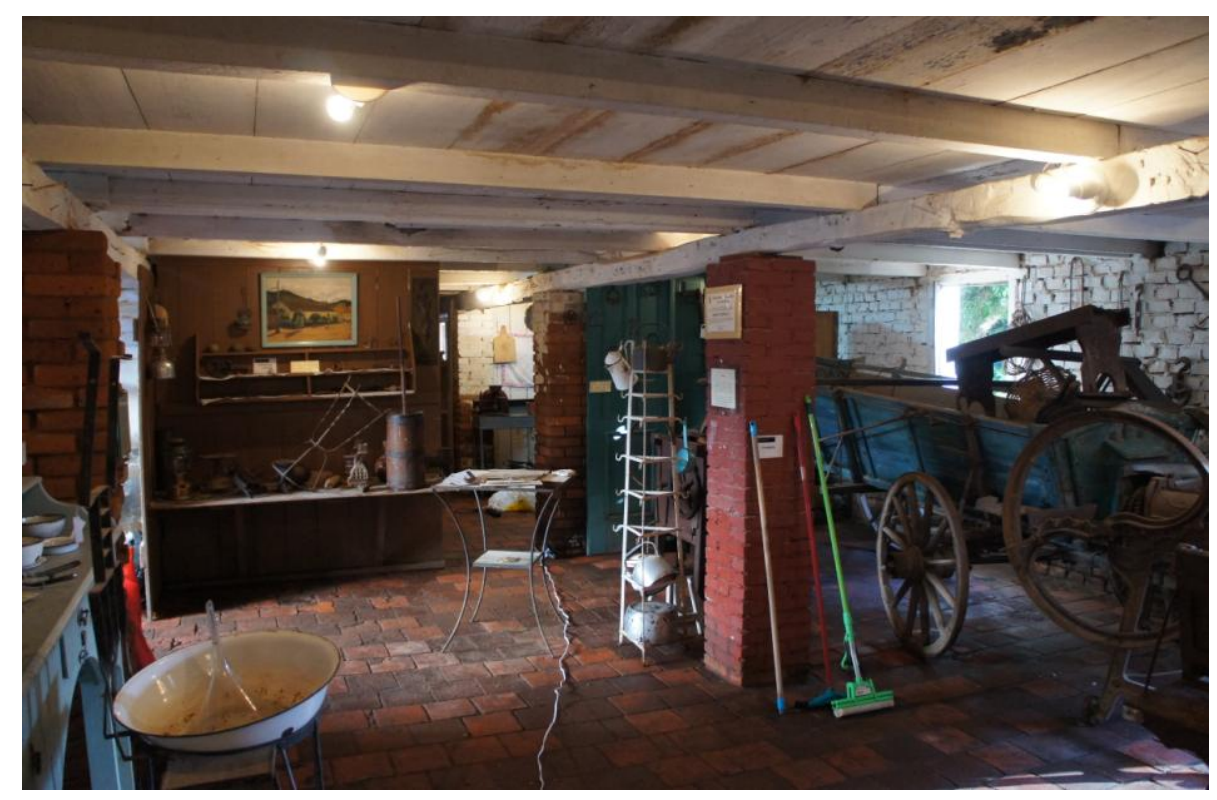

Figura 2: Situação encontrada dentro do Museu

Fonte: Acervo Museu Gruppelli, 2016 
Num primeiro momento, a equipe do Museu trabalhou no resgate dos objetos, que consistiu em limpar a lama e secar tudo. Todo esse processo foi realizado em uma ação conjunta, que convergiu os Cursos de Museologia, Conservação e Restauro, além de diversos outros colaboradores voluntários. Diversos itens do acervo, sobretudo os de suporte em papel, foram levados para os laboratórios do Curso de Conservação e Restauração, onde foi realizado um trabalho de restauração mais aprimorado (figura 3). A primeira ação foi providenciar a secagem do material. Em alguns documentos, foram feitos tratamentos de restauração, que incluiem as etapas de banhos com água deionizada, desacidificação, reencolagem, planificação e reintegração. Apesar da fragilidade dos documentos, os tratamentos puderam reconstituir em grande parte suas características originais. No grupo de documentos tratados, estão os documentos e bandeira do Time Boa Esperança (figura 4) e os livros de receitas da família, que representam a memória da culinária da região.

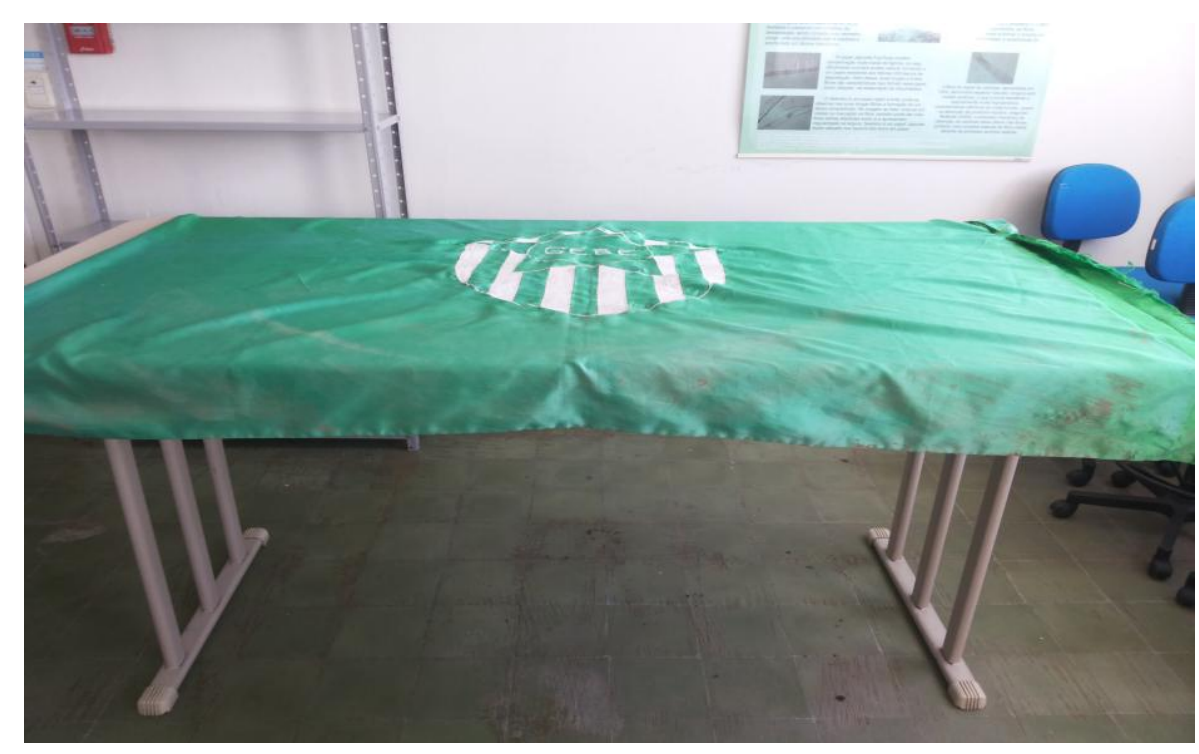

Figura 3: Bandeira do Boa Esperança sendo restaurada

Fonte: Cláudia Lacerda, 2016 


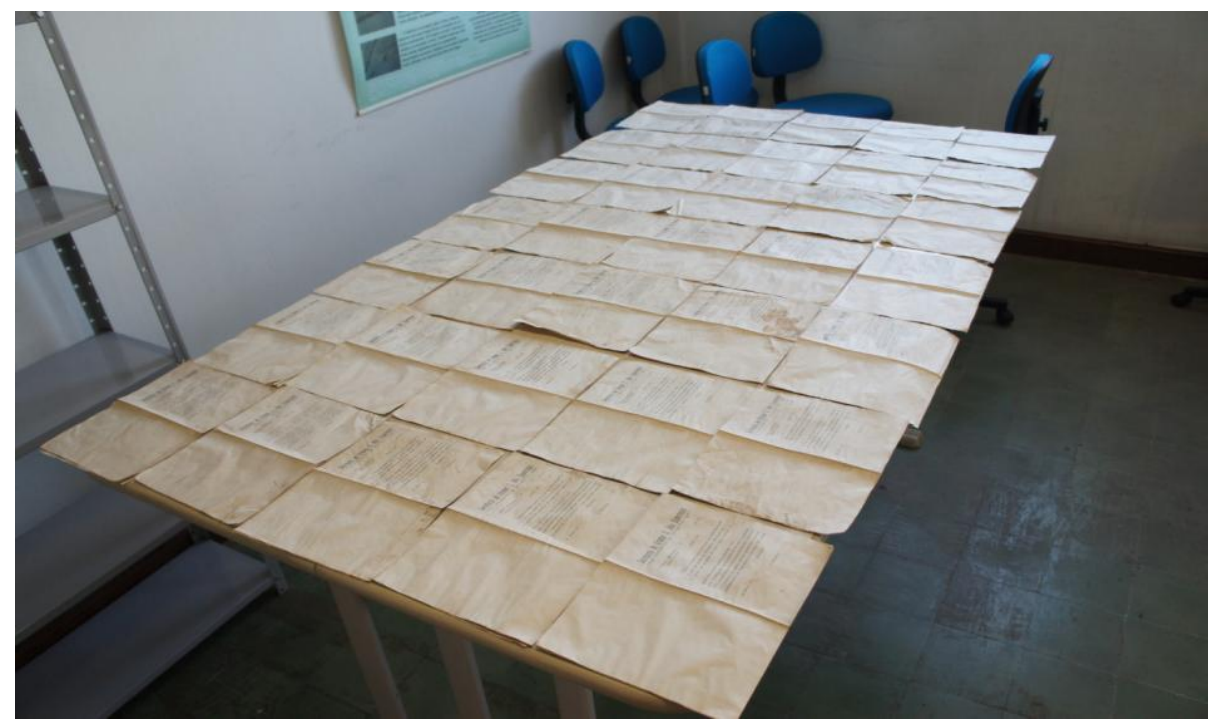

Figura 4: Documentos em restauração

Fonte: Cláudia Lacerda, 2016

Em um segundo momento, fizemos uma pesquisa sobre os objetos que fariam parte da exposição. Os critérios de seleção foram baseados na questão da musealização do ausente e dos acervos que passam por memórias trágicas.

Realizamos, ainda, 5 entrevistas com os moradores da comunidade que sofreram, de forma direta ou indireta, os efeitos da enchente. Consideramos, em termos metodológicos, a ideia de Duarte (2002), baseada em Brandão (2000), ao afirmar que a entrevista é um trabalho que exige uma atenção permanente à escuta de tudo que é falado pelo entrevistado, para, posteriormente, poder refletir sobre a forma e conteúdo da fala. Duarte diz ainda, que devem ser levados em considerações os tons, ritmos e expressões gestuais que acompanham, ou mesmo, substituem essa fala e isso exige tempo e esforço (DUARTE, 2002, p. 146). Em face da tragédia, há de ser registrado tudo aquilo que não é “dizível”, mas que é expressado de outras formas. Essa também é uma forma de representar as ausências.

Tendo em mãos representativo material, composto de objetos, restos, sobras, memórias, ações de preservação e, igualmente, de ausências resultadas da tragédia, iniciamos o processo de concepção da exposição. 


\section{O DESENVOLVIMENTO DA EXPOSIÇÃO TEMPORÁRIA}

Antes do evento trágico, pensamos, inicialmente, em realizar uma exposição temporária que retratasse as tecnologias do passado que eram utilizadas no cotidiano dos moradores da zona rural da cidade de Pelotas. Porém, devido à enchente sofrida na região, resolvemos mudar o foco da exposição. Como já mencionado, buscamos contar a história da tragédia, pela visão dos objetos, com o objetivo de humanizar os processos de musealização. Desse modo, a maioria dos textos utilizados na exposição foram escritos em primeira pessoa, tendo os objetos como narradores do ocorrido. Essa abordagem foge da tônica dos museus tradicionais, na medida em que traz à vista o contraste com o belo, o asséptico, o raro; enfim, todas aquelas características que sacralizam o ambiente museal. Do mesmo modo, trabalha com um recorte patrimonial pouco usual: a ausência como expressão de memória, visto que, parte dos objetos expostos não está em sua presença física; o que resta dos artefatos são as simbologias em justaposição com os fragmentos de representação que sobreviveram (fotografias, narrativas e as próprias memórias de parte do público).

A concepção dessa exposição foi pensada em três nichos temáticos: ausências, cicatrizes e renascimentos. O primeiro representa os objetos que foram levados pela água e não voltaram, citamos como exemplo o tacho de cobre (figura 5) que fazia parte do Museu Gruppelli. Salvaguardado e exposto no espaço museal, ele não serve somente para apresentar um artefato projetado para fazer doces, mas, sim, como indicador de memórias, "extensões de memória" (CANDAU, 2014) de um determinado grupo. No espaço museal, funciona como mediador entre as pessoas e a representação dos seus modos de vida, de sua culinária, dos modos de operação para fabricação de doces caseiros, dentre outros elementos de representação.

A biografia do tacho é enigmática, e não é reduzida a uma única versão. $\mathrm{Na}$ ausência de qualquer documentação que comprove sua chegada ao Museu, registramos, aqui, a epopeia narrada por um dos principais agenciadores do lugar, Ricardo Gruppelli. Sua história iniciaria quando teria aparecido nas redondezas do restaurante Gruppelli, em um dia de chuva. Ele teria sido trazido pelas águas de uma correnteza forte e salvo 
por um membro da família Gruppelli. Foi utilizado, por muito tempo, para o fim ao qual foi inicialmente projetado: fazer doces. Em um dado momento, um dos membros da família conseguiu enxergar um valor que sobrepujava a matéria, atribuindo-o um valor emotivo - ou espiritual. A fronteira, nem sempre muito clara, que separa o uso utilitário e simbólico, foi transposta e o tacho foi deslocando-se, física e semanticamente, para seu novo lugar: o Museu Gruppelli. A partir desse momento, ao perpassar o processo de musealização, mudou de status, passou a ser museália, ou objeto de museu.

Outro objeto perdido durante a enchente foi a cadeira marrom. Os dois foram representados em forma de fotografias. (Conforme figura 6). Nesse nicho, utilizamos ainda velas e flores que simbolizavam a morte, vídeo com imagens da enchente, bem como, uma lata de lixo com objetos destruídos, cheios de lama, com o intuito de representar o caos e a destruição.

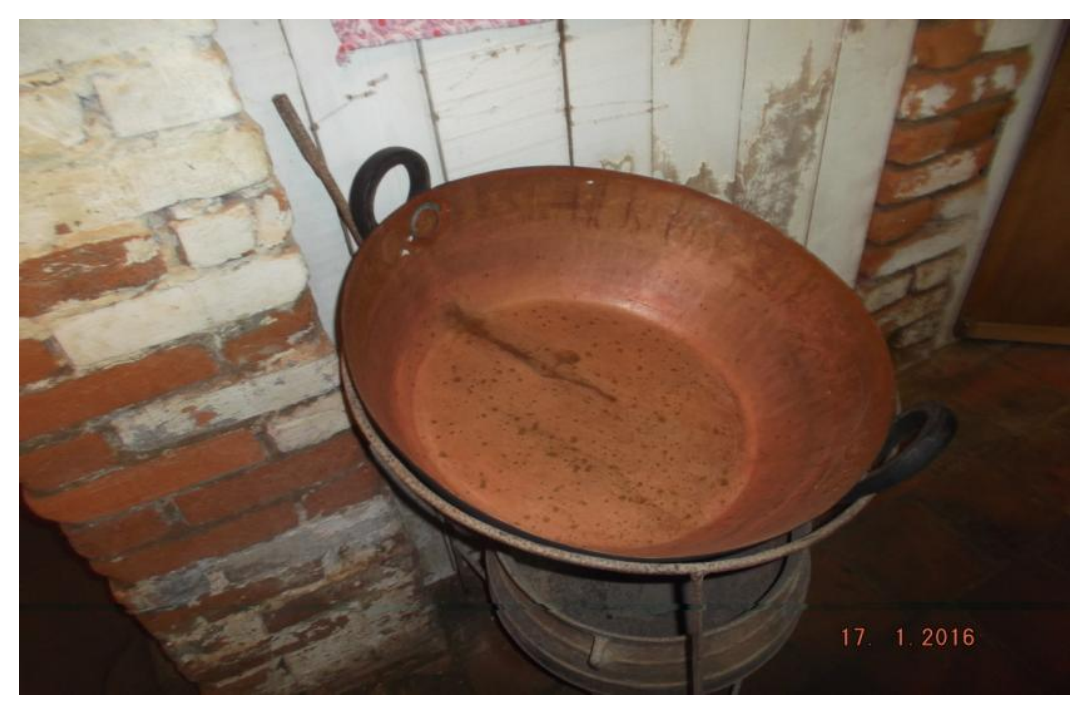

Figura 5: Tacho

Fonte: Autores, 2016 


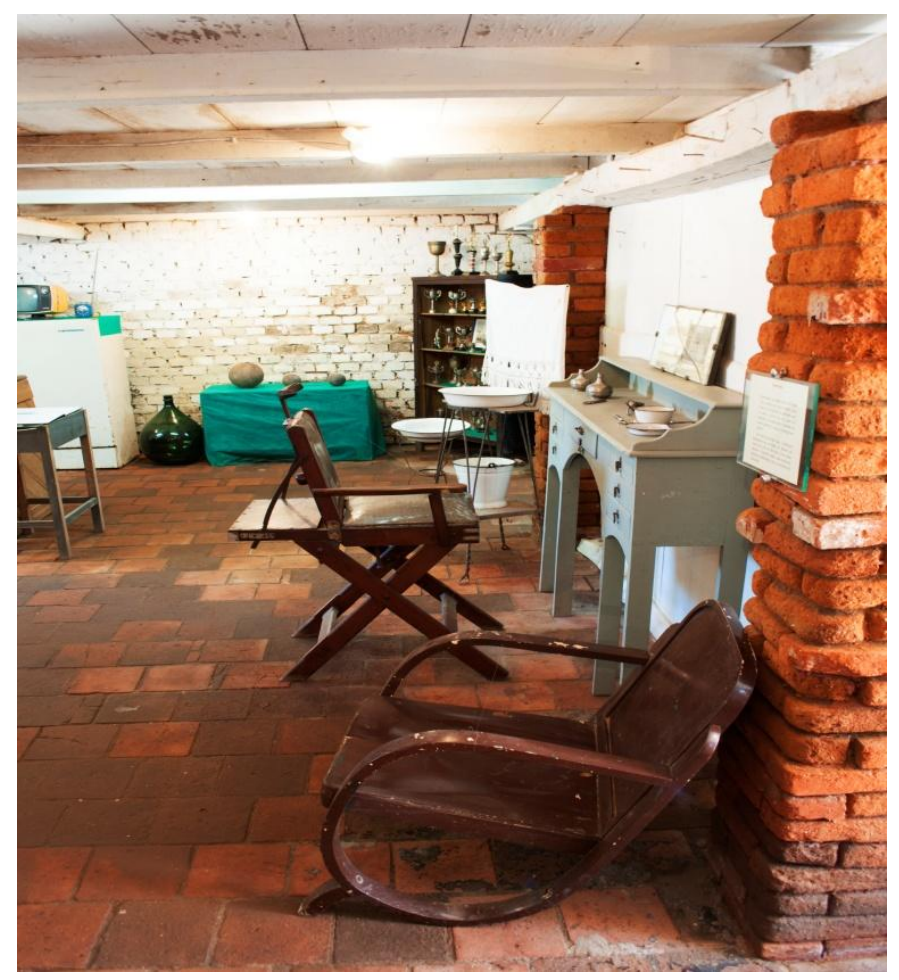

Figura 6: Cadeira marrom

Fonte: Acervo do Museu Gruppelli, 2016

No segundo nicho, fizemos uma homenagem aos objetos que retornaram com cicatrizes ao Museu, após terem sido levados pela água. Entre os objetos está o bidê, o rádio e a "gota" (figura 7), objeto representativo do Museu que era utilizado para guardar vinho e água. Para Ricardo Gruppelli (2016), esse objeto tem aproximadamente 70 anos, e sempre pertenceu à família Gruppelli. Quando se tinha menos produção de vinho, a gota era utilizada para o armazenamento do mesmo.

Esses objetos, apesar de terem retornado ao circuito museal, foram representados tal como foram encontrados; alguns ainda com restos de lama, quebrados ou com marcas irreversíveis da tragédia. As cicatrizes em questão marcam a temporalidade e as memórias trágicas pelas quais os artefatos atravessaram. 


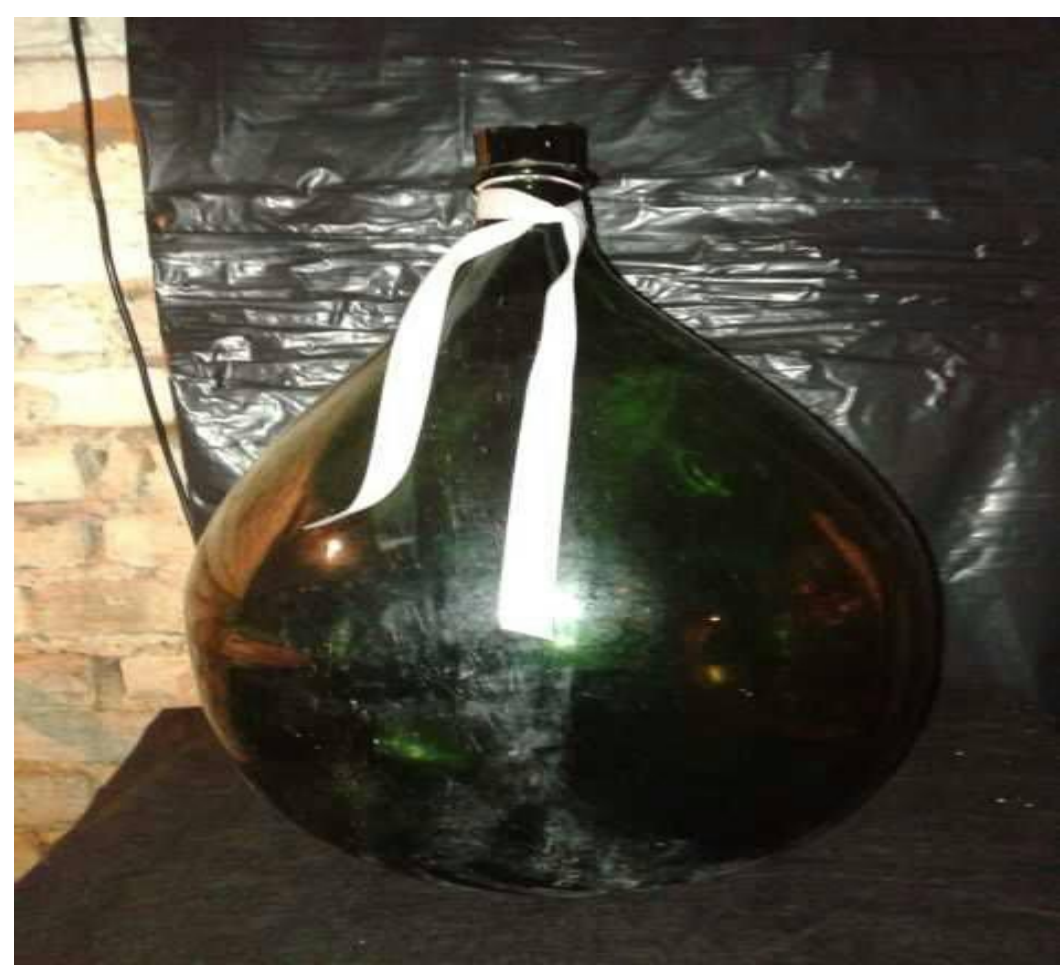

Figura 7: Gota

Fonte: Autores, 2016

É interessante destacar que os objetos, assim como as pessoas, também possuem uma história, uma biografia.

Miranda (2012, p. 76), baseado em Thierry Bonnot complementa:

As coisas, como as pessoas, possuem vidas sociais, que, no caso daquelas, começam como simples mercadoria, destinada a circulação, passando depois por sucessivas singularizações, que, esvaziando-as de sua funcionalidade, as transformam, primeiramente, em objetos de conservação, posteriormente em objetos de colecionamento e, em certos casos até, de patrimonialização.

Podemos chamar os objetos musealizados, que fizeram parte da vida das pessoas, de "objetos biográficos". Esses objetos ajudam a narrar e contar a trajetória de vida de seus usuários, relevando quem eles foram e são no mundo.

São estes os objetos que Violette Morin chama de objetos biográficos, pois envelhecem com o seu possuidor e se incorporam à sua vida: $\mathrm{o}$ relógio da família, a medalha do esportista, a máscara do etnólogo, o mapa-múndi do viajante. Cada um desses objetos representa uma experiência vivida. Penetrar na casa em questão é conhecer as aventuras afetivas de seus moradores. Daí vem a timidez que sentimos 
ao entrarmos em certos quartos em que os objetos nos revelam quem é seu dono (BOSI, 2002, p. 441).

É importante considerar que esses objetos, ao fazerem parte dos museus, têm a sua função utilitária esmaecida e lhe são atribuídos, ao atravessarem o processo de musealização, uma nova função, agora, simbólica e representacional. São considerados documentos, representações da realidade. São os processos de musealização que garantem a continuidade da biografia das coisas e das comunidades, assim como, a conexão dessas memórias com outros sujeitos-sociais, na forma de uma rede expandida e heterogênea, que convencionamos chamar de memória social.

Ao preservar e difundir as biografias desses objetos, ampliando as conexões entre objetos e pessoas, memórias e histórias, podemos falar em uma alma das coisas. Podemos ancorar esse pensamento em Silveira e Lima Filho:

É nesse sentido que é possível falar numa memória que impregna e restitui a alma das coisas, referida à uma paisagem (inter) subjetiva onde o objeto (re)situa o sujeito no mundo vivido mediante o trabalho da memória, ou ainda, é da força e dinâmica da memória coletiva , que o objeto, enquanto expressão de materialidade da cultura de um grupo social, remete à elasticidade da memória como forma de fortalecer os vínculos com o lugar, considerando as tensões próprias do esquecimento (SILVEIRA; LIMA FILHO, 2005, p. 39).

Nesse momento, o ausente se torna presente, a morte se transforma em vida. Podemos dizer que os objetos de coleções são fragmentos da vida social. Eles não existem isoladamente; se complementam na relação com os sujeitos. Em consonância com o que afirmam Gonçalves; Guimarães e Bitar (2013), compreendemos que esses artefatos são construídos pelas pessoas, ao mesmo tempo em que as pessoas são construídas pelos artefatos. São como molduras em que as memórias são forjadas e fixadas. Ou seja, sujeito e objeto estão sempre em um constante ato relacional.

Pedro Andrade (2005. p, 210) completa esse pensamento:

Em resumo, para entender o valor dos objetos, sejam eles únicos ou em série, gozando de uma vida plena de utilizações e imbuída de aspectos sócios- simbólicos ou encontrando-se integrados numa colecção, é preciso insistir nesta convicção referida supra: os objectos apresentam, simultaneamente, uma biografia individual e uma genealogia colectiva. Numa tal perspectiva, assemelham-se profundamente aos objetos, embora ostentem outro nome. Ou seja, se os objectos se revelam como inscrições dos sujeitos, também os sujeitos apresentam-se enquanto traços dos objetos. Assim sendo, as colecções de objectos são ora colecções de sujeitos escritos ou objectivados, ora grupos de objectos que, por vezes 
constroem o seu próprio (e o nosso) trajecto de vida sócio - cultural, sem que os actores sociais sempre se dêem conta disso. Os objectos coleccionam-nos tanto quanto nos os coleccionamos.

No terceiro nicho, retratamos os objetos que receberam uma nova chance de vida, por intermédio de um esforço cooperativo de diversas pessoas. Utilizamos, nessa etapa, fotos do processo de restauração dos objetos, a partir do tratamento nos laboratórios do Curso de Conservação e Restauro da UFPel. Alguns objetos restaurados foram incorporados à exposição, como a bandeira do Clube Boa Esperança, time de futebol da colônia, receitas, flâmulas, cartões e livros. Esses objetos, após longo processo de restauração, retornaram à vida patrimonial.

Para potencializar a linguagem expográfica, foram colocadas folhas de árvores de eucalipto pelo chão da exposição, para que as pessoas caminhassem sobre essas, com a intenção de provocar a sensação de caos e, ao mesmo tempo, simbolizar o barro e a lama. Foi colocado, ainda, o tecido não tecido (TNT) nas paredes, na porta de entrada da exposição, para simbolizar um ambiente penumbroso e de luto. Utilizamos, também, caixas de som para retratar a acústica da tempestade. A intenção da exposição é de impactar os visitantes por meio dos seus diversos sentidos e emoções. Desse modo, utilizamos diversos recursos multissensoriais, como mencionado acima. Tojal (2007, p. 102, 103), reforça esse pensamento, dizendo que:

a percepção multissensorial é também parte inerente de uma postura semiótica aplicada à comunicação museológica que privilegia a compreensão da recepção, a partir dos estímulos provenientes dos objetos e dos sentidos, a eles atribuídos pelo público fruidor, sendo que, nesse caso mais específico, a ênfase da recepção está vinculada à fruição do objeto cultural a partir de todos os canais sensoriais além do visual, como o tátil, auditivo, o olfativo, o paladar e o sinestésico.

Vale lembrar, ainda, que a exposição, segundo Cury (2006), é o produto final de um longo processo; é nela que o público tem acesso à poesia das coisas, em que o museu se apresenta à sociedade.

Para verificar o impacto da linguagem expositiva junto aos visitantes, estamos aplicando uma pesquisa de público. Para Almeida; Lopes (2003), a pesquisa de público é uma importante ferramenta, muito usada pelos museus, para identificar as opiniões, sugestões, emoções, comportamentos, falas, entre outros, oferecendo ao receptor um papel ativo no processo comunicacional, de sorte a estreitar a relação entre museu, patrimônio e público. 
Os resultados obtidos foram fruto de diálogos com os visitantes, registrados em caderno de campo. Foi perguntado às pessoas se a exposição lhe despertou algum sentimento. Entre as respostas mencionadas, podemos citar saudosismo, esperança, pena e lástima. Isso nos remete ao fato de que o objetivo proposto na exposição, que era impactar emocionar e sensibilizar as pessoas, vem sendo alcançado.

O público foi perguntado, ainda, sobre quanto tempo gostaria que exposição permanecesse no Museu. Praticamente todas as pessoas disseram que ela deveria ser incorporada à exposição de longa duração do Museu. Reivindicaram que a enchente, apensar de ser uma memória difícil, deveria ser registrada como um fato histórico para a região, cuja exposição cumpriria o papel de perenizar essa memória.

Vemos, aqui, que os museus não são somente espaços que afirmam memória e identidade. São, também, lugares que afloram e afirmam emoções das mais diversas. Nesse sentido, o produto e o processo museal estão ancorados na emoção patrimonial, na performance cultural. $\mathrm{O}$ trabalho museal deve ter como endereço as pessoas, tendo como referência a cultura material que alberga.

\section{CONCLUSÕES}

Como visto acima, o trabalho teve como proposta apresentar um breve relato sobre os processos de concepção, montagem e avaliação, da exposição temporária: "a vida efêmera dos objetos: um olhar pós-enchente." A partir desse breve trabalho, buscamos abrir caminho para refletir o potencial que há na musealização do ausente; no trato patrimonial de memórias traumáticas e, igualmente, ratificamos a ideia de que os museus são lugares em que emoções são agenciadas.

Ao refletir sobre o ciclo de vida dos objetos, mostrando que eles são efêmeros, colocamos em xeque outra questão: os objetos que salvaguardamos em museus e instituições congêneres de memória tendem, necessariamente, ao fim. Os processos de conservação e restauração, que ocupam parte considerável do trabalho de curadoria, tentam justamente frear a rota inevitável da morte patrimonial. A pergunta que laçamos, como provocação, redunda em: como traçar políticas de preservação quando os acervos estão fadados ao fim, seja pela própria ação do tempo, seja por eventos traumáticos? 
Esse questionamento deixa aparente a falência das políticas contemporâneas de acervos, e aponta para o desafio de preservar o ausente, ou o "vir a ser ausente".

No mesmo sentido, de forma breve e ainda superficial, buscamos sinalizar a relevância dos processos comunicativos em contexto museal, que devem ser pensadas em todas as etapas: no planejamento, montagem e avaliação. É a comunicação que assegura a real estabilidade dos objetos, não apenas sua conservação física. Justamente por isso, ocupamo-nos de explorar os variados recursos da linguagem museológica, criando uma atmosfera embebida de sons, vídeos, folhas, cheiro, objetos e sobras de objetos que, em justaposição, atiçam a vontade de memória e de preservação. Defendemos, aqui, que é pela emoção patrimonial que esses objetos serão apropriados e ganham ressonância na vida das pessoas que intercambiam memórias no Museu.

\section{REFERÊNCIAS}

ALMEIDA. Adriana; LOPES, Maria Margareth. Modelos de comunicação aplicados aos estudos de público de museus. Revista. Ciências Humanas, Taubaté, v.9, n.2, p.137-145, jul-dez. 2003.

ANDRADE, Pedro. Os objetos que coleccionavam sujeitos (estilo ou gênero de escrita): diálogos sociológicos. Episteme, Porto Alegre, n. 20, p. 206-210, jan./jun. 2005.

BOSI, Ecléa. Lembranças dos velhos. São Paulo: Companhia das Letras, 2002.

CANDAU, Joel. Memória e Identidade. São Paulo: Contexto, 2014.

CURY, Marília Xavier. Exposição: concepção, montagem e avaliação. São Paulo: Annablume, 2006.

DEBARY, Octave. Segunda mão e segunda vida: objetos, lembranças e fotografias. Revista Memória em Rede, Pelotas, v. 2, n. 3, p. 27- 45. Ago.-nov. 2010

DUARTE, Rosália. Pesquisa qualitativa; reflexões sobre o trabalho de campo. Cadernos de Pesquisa n.115, p. 139-154, mar. 2002. Disponível em: <http://www.scielo.br/pdf/cp/n115/a05n115.pdf $>$. Acesso em: 15 mai. 2015.

GONÇALVES, José Reginaldo; GUIMARÃES, Roberta; BITAR, Nina. A Alma das Coisas: patrimônios, materialidades e ressonâncias. Rio de Janeiro: Mauad X, Faperj, 2013. 
GRUPPELLI, Paulo Ricardo. [Entrevista]. 2016. Entrevista concedida a José Paulo Siefert Brahm, em 05 de junho de 2016, na cidade de Pelotas/RS.

MIRANDA, Victorino Chermont de. O problema da nostalgia nas coleções de porcelanas históricas. In: MAGALHÃES, Aline Montenegro; BEZERRA, Rafael Zamorano (Org.). Coleção e colecionadores: a polissemia das práticas. Rio de Janeiro: Museu histórico Nacional, 2012, p. 74-85.

SILVEIRA, Flávio Leonel Abreu da; LIMA FILHO, Manuel Ferreira. Por uma antropologia do objeto documental: entre a "alma nas coisas" e a coisificação do objeto. Horizonte Antropológico, Porto Alegre, ano 11, n. 23, p. 37-50, jan/jun 2005.

TOJAL, Amanda Pinto da Fonseca. Políticas Públicas de Inclusão Cultural de Públicos Especiais em Museus. 2007, 322f. Tese (Doutorado em Ciência da Informação) - Curso de Pós Graduação em Ciência da Informação, da Universidade de São Paulo. Disponível em: <http://www.teses.usp.br/teses/disponiveis/27/27151/tde19032008-183924/pt-br.php>. Acesso em: 05 mai. 2016. 